\title{
EKSISTENSI LEMBAGA ADAT MELAYU JAMBI DALAM PENYELESAIAN SENGKETA MASYARAKAT ADAT
}

\author{
Herlina Manik \\ Fakultas Hukum Universitas Jambi \\ Alamat: Jl. Jambi-Muara Bulian Km. 15 Mendalo Darat Jambi \\ herlina_manik@unja.ac.id
}

\begin{abstract}
Disputes that arise in the community can disrupt the public order. For this reason, efforts are needed so that's every dispute can be resolved so that the balance in the community order can be restored. The purpose of this study is to determine the extent of the existence of customary institutions in resolving disputes and also to find out what processes or steps are taken by traditional institutions in resolving disputes. This research was conducted in Jambi. This type of researsh is sociological juridical. Data collection was conducted through interviews, data were analyzed by qualitative analysis and presented descriptively. The results of the study show that the existence of the Jambi Malay Customary Institution in the settlement of indigenous peoples' customary law disputes still exists and still continues today. The existence of the Jambi Malay Customary Institution can be seen from its arrangement in the Jambi Province Regional Regulation (PERDA) Number 5 of 2014 concerning the Jambi Malay Customary Institution. The dispute resolution prosses are carried out in several stages, namely: the stage of summoning the parties, the stage of summoning the witness, the stage of the deliberation process and closing. After going through the deliberation process, the mediator will provide a decision / solution that if accepted by the parties will be made in the form of an agreement. But if the parties cannot accept it, the mediator gives input to proceed to the court's formal path. Jambi Province's Regional Regulation Number 5 of 2014 concerning Jambi Malay Customary Institutions can continue to be socialized and Jambi LAM is expected to be increasingly active in carrying out its duties and functions so that Jambi traditional law can be enforced in community life.
\end{abstract}

Keywords: Customary Institution, Jambi Malay, Dispute Resolution

\begin{abstract}
Abstrak
Sengketa yang timbul di masyarakat dapat mengganggu tatanan masyarakat. Untuk itu diperlukan upayaupaya agar setiap sengketa dapat diselesaikan sehingga keseimbangan dalam tatanan masyarakat dapat dipulihkan. Tujuan penelitian ini adalah untuk mengetahui sejauhmana eksistensi lembaga adat dalam menyelesaikan sengketa dan juga untuk mengetahui proses atau langkah-langkah apa saja yang dilakukan lembaga adat dalam penyelesaian sengketa. Penelitian ini dilakukan di Jambi. Jenis penelitian ini yuridis sosiologis. Pengumpulan data dilakukan melalui wawancara, data dianalisis dengan analisis kualitatif dan disajikan secara deskriptif. Hasil penelitian menunjukkan bahwa Eksistensi Lembaga Adat Melayu Jambi dalam penyelesaian sengketa adat masyarakat hukum adat masih tetap ada dan masih berjalan hingga saat ini. Keberadaan Lembaga Adat Melayu Jambi dapat dilihat dari pengaturannya dalam Peraturan Daerah (PERDA) Provinsi Jambi Nomor 5 Tahun 2014 tentang Lembaga Adat Melayu Jambi. Adapun prosses penyelesaian sengketa dilakukan dalam beberapa tahapan yakni : tahap pemanggilan para pihak, tahap pemanggilan saksi, tahap proses musyawarah dan penutup. Setelah melalui proses musyawarah, mediator akan memberikan putusan/ solusi yang jika diterima oleh para pihak maka akan dibuat dalam bentuk perjanjian. Tetapi jika para pihak tidak dapat menerimanya maka mediator memberikan masukkan untuk melanjutkan ke jalur formal pengadilan. Peraturan Daerah Provinsi Jambi Nomor 5 Tahun 2014 tentang Lembaga Adat Melayu Jambi dapat terus disosialisasikan dan LAM Jambi diharapkan semakin aktif dalam melaksanakan tugas dan fungsi agar hukum adat melayu jambi dapat ditegakkan dalam kehidupan bermasyarakat.
\end{abstract}

Kata Kunci : Lembaga Adat, Melayu Jambi, Penyelesaian Sengketa 


\section{Pendahuluan}

Manusia merupakan makhluk sosial, yang dalam kehidupannya selalu membutuhkan orang lain. Dalam kehidupan sosial tidak dapat dipungkiri dapat menimbulkan gesekan-gesekan atau perselisihan-perselisihan yang dapat menyebabkan terjadinya sengketa atau konflik. Sengketa dapat terjadi antarpribadi maupun antarkelompok. Sengketa yang timbul di masyarakat dapat mengganggu tatanan masyarakat. Untuk itu diperlukan upaya-upaya agar setiap sengketa dapat diselesaikan sehingga keseimbangan dalam tatanan masyarakat dapat dipulihkan.

Dalam kehidupan bermasyarakat terdapat berbagai tradisi mengenai bagaimana sengketa harus ditangani dan hal ini terus mengalami perkembangan. Sengketa dapat diselesaikan melalui berbagai cara, baik melalui forum formal yang disediakan oleh Negara maupun forum-forum lain yang tidak resmi disediakan oleh Negara. ${ }^{1}$

Menurut pasal 10 UU No. 48 Tahun 2009 tentang Kekuasaan Kehakiman penyelesaian sengketa dapat dilakukan dalam empat lingkungan peradilan, yaitu peradilan umum, peradilan agama, peradilan militer dan peradilan tata usaha negara. Setiap lingkungan peradilan menyelesaikan sengketa sesuai dengan yurisdiksi masing-masing. Melalui lembaga peradilan, setiap sengketa harus diselesaikan menurut tata cara formal yang diatur dalam hukum acara serta memberi hak kepada para pihak mempergunakan upaya hukum. Beberapa masyarakat memiliki kecenderungan untuk menyelesaikan sengketa melalui pengadilan namun ada pula masyarakat yang lebih suka menyelesaikan sengketa melalui forum-forum di luar pengadilan.
Selain lembaga pengadilan yang formal tersebut, penyelesaian sengketa dapat juga dilakukan di lembaga penyelesaian sengketa yang mengacu pada hukum adat.

Pada awalnya pengadilan dijadikan sebagai pilihan pertama dan terakhir dalam penyelesaian sengketa. Masyarakat memberikan kepercayaan kepada lembaga peradilan untuk menyelesaikan sengketa yang dihadapi dengan harapan akan memperoleh keadilan sebagaimana secara normatif dan eksplisit disebutkan dalam ketentuan perundang-undangan. Akan tetapi faktanya lembaga peradilan telah terbukti tidak mampu memenuhi harapan masyarakat.

Banyak keluhan yang timbul terhadap kinerja pengadilan yang dinilai formalistic, teknis dan biaya mahal. Dengan adanya penyelesaian sengketa alternatif ini, pengadilan hanya dijadikan sebagai pilihan terakhir oleh para pihak yang bersengketa.

Menurut Soerojo Wignjodipoero

"Hukum Adat itu adalah merupakan suatu kompleks norma-norma yang bersumber pada perasaan keadilan masyarakat yang selalu berkembang serta meliputi peraturan tingkah laku manusia dalam kehidupan sehari-hari dalam masyarakat, sebagian besar tidak tertulis, senantiasa ditaati dan dihormati oleh rakyat karena mempunyai akibat hukum (sanksi)"2

Hukum adat merupakan cerminan pola hidup masyarakat adat, yang lahir secara langsung sebagai penjelmaan perasaan hukum dan keadilan di dalam masyarakat adat tersebut.

Masyarakat Hukum Adat di Indonesia keberadaannya mendapat pengakuan dan perlindungan hukum yang jelas dan tegas di dalam Undang-Undang Dasar 1945 pasal 18 B ayat (2)

Eman Suparman, Pilihan Forum Arbitrase Dalam Sengketa Komersial untuk Penegakan Keadilan, Jakarta: Tata Nusa, 2004, hlm. 18.

2 Tolib Setiady, Intisari Hukum Adat Di Indonesa (Dalam Kajian Kepustakaan), Bandung: Alfabeta, 2013, hlm. 22. 
mengatur bahwa negara mengakui dan menghormati kesatuan-kesatuan masyarakat hukum adat beserta hak-hak tradisionalnya sepanjang masih hidup sesuai dengan perkembangan masyarakat dan prinsip Negara Kesatuan Republik Indonesia yang diatur dalam undang-undang.

Dalam masyarakat hukum adat, penyelesaian sengketa dilakukan dengan cara musyawarah dan mufakat melalui lembaga-lembaga adat seperti peradilan desa atau yang disebut dengan peradilan adat. Yang bertindak sebagai hakim atau pembuat keputusan dalam lembaga tersebut adalah tokoh-tokoh adat (kepala adat) dan ulama. Kewenangan dari hakim bukan hanya terbatas pada perdamaian saja tetapi juga kekuasaan memutus sengketa dalam semua bidang hukum yang tidak terbagi ke dalam pengertian pidana, perdata, publik. ${ }^{3}$

Pada dasarnya budaya untuk penyelesaian secara musyawarah atau konsiliasi merupakan nilai yang dianut masyarakat Indonesia. Di Indonesia, nilai harmoni, tenggang rasa dan komunalisme atau kebersamaan lebih diutamakan daripada individualisme. Penyelesaian melalui pendekatan consensus dengan hasil win-win solution lebih cocok daripada penyelesaian sengketa melalui jalur litigasi yang menghasilkan win lose solution. Penyelesaian sengketa melalui musyawarah diarahkan pada harmonisasi atau kerukunan dalam masyarakat serta tidak memperuncing keadaan dan sedapat mungkin menjaga kedamaian. ${ }^{4}$

Keberadaan peradilan adat atau peradilan desa dapat menjadi alternatif dalam penyelesaian sengketa bagi masyarakat. Masyarakat hukum adat meyakini bahwa lembaga peradilan ini secara sederhana dan cepat dapat menyelesaikan sengketa dalam masyarakat secara adil. Lembaga peradilan adat tidak berperan sebagai sarana pemaksa tetapi memainkan perannya sebagai mediator dalam rangka rekonsiliasi dan konsilidasi para pihak melalui proses penemuan putusan yang melegakan semua pihak, karena pada dasarnya keputusan diambil secara sukarela oleh para pihak.

Dalam perkembangannya pengakuan terhadap peradilan adat di Indonesia mengalami pasang surut. Di berbagai daerah di Indonesia, peradilan adat masih menunjukkan eksistensinya. Beberapa masyarakat hukum adat masih menggunakan lembaga peradilan adat dalam menyelesaikan sengketa. Untuk mengetahui apakah masyarakat adat melayu jambi menggunakan lembaga adat sebagai alternatif penyelesaian sengketa.

Berdasarkan pemaparan di atas, penulis merumuskan permasalahan :Bagaimana eksistensi lembaga adat dalam menyelesaikan sengketa pada masyarakat adat melayu jambi dan bagaimana proses penyelesaian sengketa yang dilakukan lembaga adat. Tujuan penelitian ini adalah untuk mengetahui sejauhmana eksistensi lembaga adat dalam menyelesaikan sengketa dan juga untuk mengetahui proses atau langkah-langkah apa saja yang dilakukan lembaga adat dalam penyelesaian sengketa.

\section{Tinjauan Pustaka}

Menurut kamus besar Bahasa Indonesia, Eksistensi adalah keberadaan, kehadiran yang mengandung unsur bertahan. Menurut pendapat ahli, eksistensi adalah: 
"Eksistensi adalah suatu proses yang dinamis, suatu, menjadi atau mengada. Ini sesuai dengan asal kata eksistensi yakni existere yang artinya keluar dari, melampaui atau mengatasi. Jadi eksistensi tidak bersifat kaku dan terhenti melainkan lentur atau kenyal dan mengalami perkembangan atau sebaliknya kemunduran tergantung pada kemampuan dalam mengaktualisasikan potensi-potensinya."

Lembaga adat merupakan kata yang berasal dari gabungan kata lembaga dan kata adat. Kata lembaga dalam bahasa inggris disebut dengan institution yang berarti pendirian, lembaga, dan kata adat berarti kebiasaan. Menurut ilmu budaya, lembaga adat diartikan sebagai bentuk organisasi adat yang tersusun relative tetap atas pola-pola kelakuan, peranan-peranan dan relasi-relasi yang terarah dan mengikut individu, mempunyai otoritas formal dan sanksi hukum adat guna tercapainya kebutuhan-kebutuhan dasar.

Menurut Peraturan Menteri Dalam Negeri
Nomor 5 Tahun 2007 tentang Pedoman
Penataan Lembaga Kemasyarakatan,
Lembaga Adat adalah lembaga
kemasyarakatan baik yang sengaja dibentuk
maupun yang secara wajar telah tumbuh dan
berkembang di dalam sejarah masyarakat atau
dalam suat masyarakat hukum adat tertentu
dengan wilayah hukum dan hak atas harta
kekayaan di dalam hukum adat tersebut, serta
berhak dan berwenang untuk mengatur,
mengurus dan menyelesaikan berbagai
permasalahan kehidupan yang berkaitan
dengan dan mengacu pada adat istiadat dan
hukum adat yang berlaku Fungsi Lembaga Adat

Lembaga adat befungsi bersama pemerintah merencanakan, mengarahkan, mensinergikan program pembangunan agar sesuai dengan tata nilai adat istiadat dan kebiasaankebiasaan yang berkembang dalam masyarakat demi terwujudnya keselarasan, keserasian, keseimbangan, keadilan dan kesejahteraan masyarakat.

Selain itu lembaga adat juga berfungsi sebagai alat kontrol keamanan, ketentraman, kerukunan dan ketertian masyarakat baik preventif maupun represif, antara lain :

a. Menyelesaikan masalah sosial kemasyarakatan

b. Penengah (hakim perdamaian) mendamaikan sengketa yang timbul di masyarakat.

Kemudian lembaga adat juga memiliki fungsi lain yaitu :

a. Membantu pemerintah dalam kelancaran dan pelaksanaan pembangunan di segala bidang terutama dalam bidang keagamaan, kebudayaan dan kemasyarakatan.

b. Melaksanakan hukum adat dan istiadat dalam desa adatnya

c. Memberikan kedudukan hukum menurut adat terhadap hal-hal yang berhubungan dengan kepentingan hubungan sosial kepadatan dan keagamaan

d. Membina dan mengembangkan nilai-nilai adat dalam rangka memperkaya, melestarikan dan mengembangkan kebudayaan nasional pada umumnya dan kebudayaan adat khususnya.

e. Menjaga, memelihara dan memanfaatkan kekayaan desa adat untuk kesejahteraan masyarakat desa adat.

Sengketa adalah suatu pertentangan atas kepentingan, tujuan dan/atau pemahaman antara 2 (dua) pihak atau lebih. Sengketa akanmenjadi masalah hukum apabila pertentangan tersebut 
menimbulkan perebutan hak, pembelaan atau perlawanan terhadap hak yang dilanggar, dan atau tuntutan terhadap kewajiban atau tanggung jawab. ${ }^{5}$ Kamus Besar Bahasa Indonesia mendefinisikan sengketa adalah pertentangan atau konflik, Konflik berarti adanya oposisi atau pertentangan antara orang-orang, kelompokkelompok, atau organisasi-organisasi terhadap satu objek permasalahan. Sengketa adalah perselisihan yang terjadi antara pihak-pihak dalam perjanjian karena adanya wanprestasi yang dilakukan oleh salah satu pihak dalam perjanjian. ${ }^{6}$

Hal yang sama juga disampaikan oleh Takdir Rahmadi yang mengartikan bahwa konflik atau sengketa merupakan situasi dan kondisi dimana orang-orang saling mengalami perselisihan yang bersifat faktual maupun perselisihanperselisihan yang ada pada persepsi mereka saja. ${ }^{7}$

\section{Sebab-sebab Timbulnya Sengketa}

Berikut ini beberapa teori tentang sebabsebab timbulnyasengketa, antara lain:

a. Teori hubungan masyarakat Teori hubungan masyarakat, menitikberatkan adanya ketidakpercayaan dan rivalisasi kelompok dalam masyarakat. Para penganut teori ini memberikan solusisolusi terhadap konflik-konflik yang timbul dengan cara peningkatan komunikasi dan saling pengertian antara kelompokkelompok yang mengalami konflik, serta pengembangan toleransi agar masyarakat lebih bisa saling menerima keberagaman dalam masyarakat b. Teori negosiasi prinsip Teori negosiasi prinsip menjelaskan bahwa konflik terjadikarena adanya perbedaanperbedaan diantara para pihak. Para penganjur teori ini berpendapat bahwa agar sebuah konflik dapat diselesaikan, maka pelaku harus mampu memisahkan perasaan pribadinya dengan masalahmasalah dan mampu melakukan negosiasi berdasarkan kepentingan dan bukan pada posisi yang sudah tetap. ${ }^{8}$

c. Teori identitas

Teori ini menjelaskan bahwa konflik terjadi karena sekelompok orang merasa identitasnya terancam oleh pihak lain. Penganut teori identitas mengusulkan penyelesaian konflik karena identitas yang terancam dilakukan melalui fasilitasi lokakarya dan dialog anatara wakil-wakil kelompok yang mengalami konflik dengan tujuan mengidentifikasikan ancamanancaman dan kekhawatiran yang mereka rasakan serta membangun empati dan rekonsiliasi. Tujuan akhirnya adalah pencapaian kesepakatan bersama yang mengakui identitas pokok semua pihak.

d. Teori kesalahpahaman antar budaya Teori kesalahpahaman antar budaya menjelaskan bahwa konflik terjadi karena ketidakcockan dalam berkomunikasi diantara orang-orang dari latar belakang budaya yang berbeda. Untuk itu diperlukan dialog antara orang-orang yang mengalami konflik guna mengenal dan memahami

\footnotetext{
Sengketa, diakses secara online di:http://www.bakti-arb.org/arbitrase.html, pada tanggal 30 juni 2019 pukul 17.08 WIB Nurnaningsih Amriani, Mediasi Alternatif Penyelesaian Sengketa Perdata Di Pengadilan, Jakarta: PT. Raja Grafindo Persada, 2012, hlm. 13.

Takdir Rahmadi, Mediasi Penyelesaian Sengketa Melalui Pendekatan Mudakat, Jakarta: PT.Raja Grafindo Persada, 2010, hlm. 1.

$8 \quad$ Ibid, hlm. 8.
} 
budaya masyarakat lainnya, mengurangi streotipe yang mereka miliki terhadap pihak lain.

e. Teori transformasi

Teori ini menjelaskan bahwa konflik dapat terjadi karena adanya masalah-masalah ketidaksetaraan dan ketidakadilan serta kesenjangan yang terwujud dalam berbagai aspek kehidupan masyarakat baik sosial, ekonomi maupun politik. Penganut teori ini berpendapat bahwa penyelesaian konflik dapat dilakukan melalui beberapa upaya seperti perubahan struktur dan kerangka kerja yang menyebaban ketidaksetaraan, peningkatan hubungan dan sikap jangka panjang para pihak yang mengalami konflik serta pengembangan proses-proses dan sistem untuk mewujudkan pemberdayaan, keadilan rekonsiliasi dan pengakuan keberadaan masing-masing. ${ }^{9}$

f. Teori kebutuhan atau kepentingan manusia Pada intinya, teori ini mengungkapkan bahwa konflik dapat terjadi karena kebutuhan atau kepentingan manusia tidak dapat terpenuhi/terhalangi atau merasa dihalangi oleh orang/pihak laim. Kebutuhan dan kepentingan manusia dapat dibedakan menjadi tiga jenis yaitu substantif, prosedural dan psikologis. Kepentingan substantif berkaitan dengan kebutuhan manusia yang berhubungan dengan kebendaan seperti uang, sandang, pangan, papan/rumah dan kekayaan. Kepentingan prosedural berkaitan dengan tata dalam pergaulan masyarakat sedangkan kepentingan psikologis berhubungan dengan non materiil atau bukan kebendaan seperti penghargaan dan empati.

\section{Penyelesaian Sengkta melalui Litigasi}

Proses penyelesaian sengketa yang dilakukan melalui pengadilan atau yang sering disebut dengan istilah "litigasi" yaitu suatu penyelesaian sengketa yang dilaksanakan dengan proses beracara di Pengadilan dimana kewenangan untuk mengatur dan memutuskanya dilaksanakan oleh hakim.

Litigasi merupakan proses penyelesaian sengketa di pengadilan dimana semua pihak yang bersengketa saling berhadapan satu sama lain untuk mempertahankan hak-haknya di Pengadilan. Hasil akhir dari suatu penyelesaia sengketa melalui litigasi adalah putusan yang menyatak win-lose solution. ${ }^{10}$

Prosedur dalam jalur litigasi ini sifatnya lebih formil dan teknis, ,mengahsilkan kesepakatan yang bersifat menang kalah cenderung menimbulkan masalah baru, lambat penyelesaiannya, membutuhkan biaya yang mahal, tidak responsif dan menimbulkan permusuhan antara para pihak yang bersengketa. Kondisi ini menyebabkan masyarakat mencari alternatif yaitu penyelesaian di luar proses peradilan formal, penyelesaian sengketa di luar proses peradilan formal ini lah yang disebut dengan "alternative Dispute Resolution atau ADR.

\section{Penyelesaian Sengketa melalui Non-Litigasi}

Dalam penyelesaian sengketa melalui nonlitigasi, kita telah mengenal adanya penyelesaian sengketa alternatif yang dalam perspektif undang- 
undang nomor 30 tahun 1999 tentang arbitrase dan alternatif penyelesaian sengketa, ADR adalah suatu pranata penyelesaian sengketa di luar pengadilan berdasarkan kesepakatan para pihak dengan mengesampingkan penyelesaian sengketa secara litigasi di pengadilan.

\section{Metode Penelitian}

Penelitian ini mendasarkan pada penelitian hukum yang dilakukan dengan pendekatan yuridis sosiologis. Penelitian yuridis sosiologis adalah suatu penelitian yang didasarkan pada suatu ketentuan hukum dan fenomena atau kejadian yang terjadi di lapangan. ${ }^{11}$

Memberikan arti penting pada langkah observasi dan analisis yang bersifat empiris. Dalam penelitian iini yang akan dicari perihal eksistensi lembaga adat melayu jambi sebagai alternatif dalam penyelesaian sengketa masyarakat di jambi. Tipe kajian dalam penelitian ini secara spesifik lebih bersifat deskriptif, metode deskriptif ini dimaksudkan untuk memperoleh gambaran yang baik, jelas, dan dapat memberikan data sdetail mungkin tentang obyek teliti dalam hal ini untuk menggambarkan bagaimana eksistensi lembaga adat melayu jambi dalam penyelesaian sengketa masyarakat di Jambi.

Sumber data yang penulis peroleh dalam penelitan ini ada dua macam data yaitu Data primer yaitu data yang diperoleh melalui wawancara dengan melakukan interview dengan narasumber dan responden atau sampel yang berhubungan dnegan penelitian ini. Data sekunde yaitu data yang diperoleh dengan cara mempelajari berbagai literatur yang berkaitan dengan masalah yang diteliti, terdiri atas: buku-buku, majalah hukum, artikel ilmiah, arsip-arsip mendukun publikasi dari lembaga terkait.

Teknik pengumpulan data yang penulis gunakan antara lain: Studi kepustakaan/dokumentasi yaitu mempelajari bahan-bahan tertulis berupa buku-buku, dokumen-dokumen resmi, peraturan perundang-undangan, berkas perkara serta sumber tertulis lainnya yang berkaitan dengan masalah yang diteliti. Penelitian Lapangan (Field Research) dilakukan dengan cara melakukan proses terjun langsung secara aktif ke lapangan untuk meneliti obyek penelitian tersebut. Di dalam penelitian ini data yang digunakan dalam menganalisis adalah dengan menggunakan metode analisis kualitatif. Analisis kualitatif adalah suatu cara yang dinyatakan oleh responden secara tertulis atau lisan dan perilaku nyata. Diteliti sesuatu yang utuh. ${ }^{12}$

Analisis penelitian ini dilakukan mulai dari tahap pengumpulan data-data baik yang berasal dari bahan kepustakaan maupun hasil penelitian lapangan, kemudian data-data tersebut diseleksi dan disesuaikan dengan objek dan sasaran penelitian. Proses analisa data dilakukan dengn menginteraksikan data antara data lapangan.

\section{PEMBAHASAN}

\subsection{Eksistensi Lembaga Adat Dalam Penyelesaian Sengketa}

Pengertian lembaga adat menurut Peraturan Menteri Dalam Negeri Nomor 5 Tahun 2007 tentang Pedoman Penataan Lembaga Kemasyarakatan, lembaga adat adalah lembaga kemasyarakatan baik yang sengaja dibentuk maupun yang secara wajar telah tumbuh dan

11 Soerjono Soekanto, Penelitian Hukum Normatif Suatu Tinjuan Singkat, Jakarta: Raja Grafindo, 2001, hlm. 26.

12 Ibid. 
berkembang di dalam sejarah masyarakat atau dalam suatu masyarakat adat tertentu dengan wilayah hukum dan hak atas harta kekayaan di dalam hukum adat tersebut serta berhak dan berwenang untuk mengatur, mengurus dan menyelesaikan berbagai permasalahan kehidupan yang berkaitan dengan dan mengacu pada adat istiadat dan huku adat yang berlaku.

Adat melayu jambi adalah sistem pandangan hidup masyarakat jambi yang kokoh seperti yang tersirat dalam seloko ; Titian teras betanggi batu, cermin yang tidak kabur, lantak nan tidak goyah, dak lapuk dek hujan dak lekang dek panas, kato nan saiyo, adat bersendi syara', syara' bersendi kitabullah, syara' mengato, adat memakai.

Hukum adat melayu jambi adalah hukum adat yang berlandaskan Adat bersendi syara', syara' bersendikan kitabullah. Adat melayu jambi berisi nilai-nilai, aturan-aturan, norma dan kebiasaankebiasaan kuat dan benar serta menjadi pedoman dalam penataan tatanan masyarakat, sistem hukum, sistem kepemimpinan dan pemerintahan yang dipegang teguh masyarakat melayu jambi dnegan sistem sanksi yang tegas jika anggota melakukan pelanggaran.

Eksistensi Lembaga Adat Melayu Jambi dalam penyelesaian sengketa adat masyarakat hukum adat masih tetap ada dan masih berjalan hingga saat ini. Keberadaan Lembaga Adat Melayu Jambi dapat dilihat dari pengaturannya dalam Peraturan Daerah (PERDA) Provinsi Jambi Nomor 5 Tahun 2014 tentang Lembaga Adat Melayu Jambi.

Lembaga adat melayu jambi selanjutnya disingkat LAM Jambi adalah organisasi kemasyrakatan yang karena kesejarahan atau asal usulnya menegakkan hukum adat dan mendorong anggota-anggotanya untuk melakukan kegiatan pelestarian dan pengembangan adat melayu jambi. LAM Jambi bertujuan:

a. menggali, membina, melestarikan, memelihara dan mengembangkan nilai-nilai adat dan nilai-nilai sosial budaya Melayu Jambi sebagai landasan memperkuat dan memperkokoh jati diri masyarakat melay jambi; dan

b. melindungi dan membela hak-hak tradisional dan konstitusional masyarakat adat dan nilai sosial budaya melayu jambi untuk kepentingan peningkatan kesejahteraan lahiriah dan batiniah masyarakat melayu jambi.

Pengaturan mengenai LAM Jambi dimuat dalam Perda Provinsi Jambi Nomor 2 Tahun 2014, yang mana LAM Jambi memiliki tugas untuk dapat menjadi mediator dan fasilitator jika terjadi konflik baik di tingkat kelurahan, kecamatan, kabupaten/kota dan provinsi. Dalam melaksanakan tugasnya tersebut LAM Jambi wajib melakukan hubungan kerja sama dengan Aparat penegak hukum.

LAM Jambi mempunyai kewenangan untuk menegakkan hukum adat jambi. Hukum adat jambi yang dipakai pada saat sekarang ini merupakan warisan dari Hukum Negara Kerajaan Islam Melayu Jambi 1502-1906 M hasil Rapat Besar Adat (RBA) di Bukit Siguntang 1502M, adat dipadu syarak, syarak bersandi kitabullah. Pada hari kamis tanggal $1 \mathrm{Al}-$ Muharam tahun $920 \mathrm{H}-1502 \mathrm{M}$, ditutup dengan Proklamasi Orang Kayo Hitam selaku Raja Melayu Jambi, berisi antara lain: 
a. Melayu Jambi resmi menjadi kerajaan Islam

b. Adat dipadu dengan Syarak

c. Dasar Negara adalah Pucuk Adat Rumpun Taliti (PU)

d. Hukum Dasar (UUD) Kerajaan lalam adalah Adat Nan Empat

e. Hukum Adat Melayu Jambi 9(sem bilan) pucuk

f. Bahasa adalah Melayu, Tulisan adalah Arab Melayu Jambi.

RBA Bukit Siguntang 1502M tsb, dihadiri oleh para Tokoh Adat dan Tokoh Agama Islam, tidak ada utusan dari agama lain, maka ditetapkan agama islam jadi agama resmi Kerajaan Islam Melayu Jambi, dipadu Hukum Adat dengan Hukum Syarak (Islam) dijadikan sendi hukum adat, "Adat basendi syarak, syarak basendi kitabullah". Syarak nan qawi adat nan lazim, Syarak mangato adat memakai, Haram kato syarak dihukum kato adat, Larang kato syarak pantang kato adat, wajib kato sayrak perintah kato adat.

\section{Proses Penyelesaian Sengketa}

Penyelesaian sengketa adat harus dilakukan di dalam sebuah rumah, boleh di rumah siapa saja yang ada dalam Kampung dari perkara yang diperiksa. Rumah tempat sidang penyelesaian sengketa adat disebut "Rumah Deih Rumah Telli Rumah Jenang Pendopo Rajo". Dalam Hukum Adat 9 Pucuk melarang hakim adat bersidang di luar rumah, melarang putusan jatuh di luar Rumah Adat. Selama persidangan berlangsung Rumah Adat dijaga oleh Hulubalang dan tidak ada yang boleh mendekat selain yang berkepentingan, yakni hakim adat, serta saksi-saksi yang dipanggil.
Berdasarkan hasil wawancara dengan pengurus lembaga adat melayu jambi, adapun tahapan-tahapan dalam penyelesaian sengketa masyarakat adat adalah sebagai berikut :

a. Pemanggilan pihak yang bersengketa

Pada tahap ini pihak yang bersengketa diminta hadir untuk mengemukakan masalah apa yang sedang disengketakan dan menunjukkan bukti-bukti dari persengketaan tersebut. Para pihak diberi kesempatan untuk saling mempertahankan kebenaran.

b. Pemanggilan saksi

Pada tahap ini dilakukan pemanggilan saksi umtuk didengarkan kesaksian yang memperkuat pembuktian terhadap keterangan dari para pihak. Para saksi disini adalah orang lain yang telah mengalami, melihat dan mendengar sepengetahuannya tentang duduk perkara dari sengketa.

c. Proses musyawarah

Sebelum memulai rapat lembaga adat yang berperan sebagai juru penengah mulai mempersiapkan musyawarah di tempat dan waktu yang telah ditentukan berdasarkan undangan yang telah diberikan kepada para pihak yang terlibat dalam sengketa.

Juru penengah atau mediator akan berusaha mengkondisikan agar semua pihak yang hadir memusatkan perhatiannya pada musyawarah sehingga dapat berjalan secara efektif dan musyawarah berjalan secara kekeluargaan. Apabila kondisi tenpat musyawarah dianggap kondusif dan 
para peserta musyawarah telah fokus untuk memulai rapat maka mediator akan memulai musyawarah dengan diawali doa bersama menurut agama dan kepercayaan masing-masing.

Setelah melakukan doa, mediator memulai memberikan kata sambutan yang intinya ucapan terima kasih kepada semua yang hadir dalam musyawarah tersebut. Hal penting yang disampaikan oleh mediator khususnya kepada para saksi agar dapat menyampaikam kesaksiannya secara jujur dan sesuai dengan apa yang diketahuinya. Karena keberadaan saksi dimaksudkan untuk mencari kebenaran nyata sehingga akan bermanfaat bagi semua pihak dan akan dihasilkan kesepakatan sehingga akan mengembalikan keadaan masyarakat dan segala aspeknya pada kondisi yang normal seperti sebelum terjadi sengketa.

Jika mediator menggap bahwa para peserta musyawarah telah memahami maksud dan tujuan diadakannya musyawarah tersebut maka mediator akan memberikan kesempatan kepada para pihak yang bersengketa secara bergantian menyampaikan ahal-hal yang merupakan penyimpangan-penyimpangan yang telah dilakukan pihak lain yang mengakibatkan timbulnya persengketaan.

Dalam proses ini para pihak yang bersengketa akan bertindak sendiri dan tidak memberikan kuasa kepada pihak lain untuk mewakilinya sehingga permasalahan tidak melebar karena kepentingan dan permasalahan dari para pihak akan dengan mudah diketahui oleh mediator dan pihak lain yang berkepentingan. Selain itu para pihak dapat dengan mudah menyampaikan apa yang diinginkannya langsung kepada pihak lainnya dan juga mediator.

Kesempatan pertama untuk menyampaikan hal-hal yang menjadi kepentingannya biasanya diberikan kepada pihak pemohon. Pada kesempatan ini pemohon akan menyampaikan dalil-dalil dan bukti-bukti yang dimiliki. Apabila semua tahap sudah dilalui maka kesempatan selanjutnya akan diberikan kepada juru penengah untuk menyampaikan pendapatnya berdasarkan keahliannya. Juru penengah akan memberikan pendapatnya dengan berdasarkan keadaan masyarakat yang ada mana di dalamnya terdapat berbagai aspek yang menjadi pertimbangannya sehingga penyelesaian sengketa tidak dapat diputuskan hanya berdasarkan aspekaspek tertentu saja.

Selanjutnya mendengarkan keterangan saksi-saksi yang diajukan oleh kedua belah pihak. Saksi dari pihak termohonlah yang pertama kali diberi kesempatan untuk menyampaikan kesaksiannya. Dalam menyampaikan kesaksiannya saksi dapat menyampaikan atas inisiatif dari mediator. Dari jawaban atas pertanyaan yang diajukan kepada saksi maka akan dapat membantu mediator untuk menemukan solusi atas sengketa yang sedang dimusyawarahkan untuk bahan pertimbangan penyelesaiannya.

Setelah para pihak dirasa cukup menyampaikan dalil-dalilnya dan segala kepentingannya yang terkait dengan bidang tang yang disengketakan serta kesaksian yang disampaikan maka mediator akan memberikan kesempatan lagi kepeada para pihak untuk memberikan penawaran solusinya masing-masing terhadap sengketa yang dimusyawarahkan Mediator 
dengan pengalamannya yang luas dengan mudah menemukan penyelesaian bagi sengketa yang ditanganinya karena pada dasarnya sengketa yang terjaadi antara satu dan yang lainnya didalamnya terdapat kesamaan.

Penyelesaian sengketa alternatif melalui lembaga adat digunakan untuk menyelesaikan sengketa dengan msksud mencari penyelesaian secara win-win solution yaitu suatu bentuk penyelesaian yang menguntungkan kedua belah pihak yang bersengketa karena tidak ada menang atau kalah, keduanya mempunyai kedudukan yang sama. Apabila dalam penyelesaian sengketa alternatif yang telah dilakukan mengalami jalan butu karena kedua belah pihak tidak menerima solusi yang ditawarkan mediator maka mediator akan tetap bersedia sebagai fasilitator sampai dicapai kata sepakat atau ditemukan jalan keluar yang terbaik bagi sengketa dan kedua belah pihak merasa puas atas kesepakatan tersebut. Apabila setelah melewati beberapa kali pertemuan oleh mediator yang sama tetap tidak menemukan jalan keluar maka mediator menyarankan agar sengketa tersebut diselesaikan lewat pengadilan. Tahap akhir merupakan tahap dalam proses penyelesaian sengketa secara musyawarah. Pada tahap ini mediator akan menyimpulkan apa yang dibicarakan sebelumnya dalam musyawarah. Apabila dalam musyawarah tersebut telah diperoleh kesepakatan mengenai solusi bagi sengketa yang terjadi maka kesepakatan tersebut dapat dibuat dalam bentuk perjanjian tertulis. Bila solusi tersebut diterima oleh para pihak yang bersengketa, mediator akan menjadwalkan lagi musyawarah selanjutnya tetapi apabila para pihak menolak untuk melakukan musyawarah lagi maka mediator menganjurkan para pihak untuk menyelesaikan lewat jalur yang lebih formal melalui jalur hukum.

\section{Kesimpulan}

Hasil penelitian menunjukkan bahwa eksistensi lembaga adat melayu dalam penyelesaian sengketa masih ada dan diatur dalam Peraturan Daerah Provinsi Jambi Nomor 5 Tahun 2014 tentang Lembaga Adat Melayu Jambi. Dimana salah satu tugas dari LAM Jambi adalah sebagai mediator dan fasilitator apabila terjadi konflik baik di tingkat desa/kelurahan, kecamatan, kabupaten/kota dan Provinsi. Adapun prosses penyelesaian sengketa dilakukan dalam beberapa tahapan yakni : tahap pemanggilan para pihak, tahap pemanggilan saksi, tahap proses musyawarah dan penutup. Dimana dalam tahap pemanggilan para pihak diberikan kesempatan untuk menyampaikan dalil-dalil dan bukti-bukti, dan pada tahap saksi diberikan kesempatan untuk menyampaikan kesaksian yang dialaminya langsung. Pada proses ini para pihak bertindak untuk diri sendiri dan tidak diperkenankan diwakilkan oleh orang lain (dikuasakan). Setelah melalui proses musyawarah, mediator akan memberikan putusan/ solusi yang jika diterima oleh para pihak maka akan dibuat dalam bentuk perjanjian. Tetapi jika para pihak tidak dapat menerimanya maka mediator memberikan masukkan untuk melanjutkan ke jalur formal pengadilan. Peraturan Daerah Provinsi Jambi Nomor 5 Tahun 2014 tentang Lembaga Adat Melayu Jambi dapat terus disosialisasikan dan LAM Jambi diharapkan semakin aktif dalam melaksanakan tugas dan fungsi agar hukum adat melayu jambi 
dapat ditegakkan dalam kehidupan bermasyarakat.

\section{DAFTAR PUSTAKA}

\section{A. Buku}

Amriani Nurnaningsih, Mediasi Alternatif Penyelesaian Sengketa Perdata di Pengadilan, Jakarta: PT. Raja Grafindo Persada, 2012.

Hadikusuma Hilman, Pengantar IImu Hukum Adat di Indonesia, Bandung: Mandar Maju, 2003.

Rahmadi Takdir, Mediasi Penyelesaian Sengketa Melalui Pendekatan Mudakat, Jakarta: PT.Raja Grafindo Persada, 2010.

Setiady Tolib, Intisari Hukum Adat Di Indonesa (Dalam Kajian Kepustakaan),Bandung: Alfabeta, 2012.
Soekanto Soerjono, Penelitian Hukum Normatif Suatu Tinjuan Singkat, Jakarta: Raja Grafindo, 2001.

Suparman Eman, Pilihan Forum Arbitrase Dalam Sengketa Komersial untuk Penegakan, Jakarta: Tata Nusa, 2004.

\section{B. Peraturan Perundang-undangan}

Peraturan Menteri Dalam Negeri Nomor 5 Tahun 2007 tentang Pedoman Penataan Lembaga Kemasyarakat.

Peraturan Daerah Provinsi Jambi Nomor 2 Tahun 2014 Tentang Lembaga Adat Melayu Jambi. 